\title{
Effect of Brand Loyalty on Purchase Intention in Cosmetics Industry
}

\author{
Shahid Hameed (Corresponding author) \\ Department of management sciences islamia university, Bahawalpur \\ E-mail: Shahid_pk88@yahoo.com \\ Munaza Kanwal \\ Department of management sciences islamia university, Bahawalpur \\ E-mail: Munaza9225@yhaoo.com
}

Received: March 9, 2017

doi:10.5296/rbm.v5i1.12704
Accepted: March 22, 2017

Published: February 20, 2018

URL: http://dx.doi.org/10.5296/rbm.v5i1.12704

\begin{abstract}
There is a huge expenditure for cosmetics estimated around the world. Many competitors try to capture the market and compete aggressively. The principle of this study is to examine the impact of brand loyalty on the purchase intention of customer or evaluate that how much buying behavior of consumer are influenced by brand loyalty and what factors or variable influence the brand loyalty. There are six variables that influence on brand loyalty is brand name, product quality, price, design, promotion, store environment. The 80 questioner is filled from the female consumer of cosmetic product to investigate the purchase intention influenced by brand loyalty. For this purpose linear regression method used for analysis. The result of this study shows that there is a positive significant impact of brand loyalty on purchase intention and also there is a positive significant relationship between the variables (brand name, product quality, price, design, promotion, store environment) and brand loyalty of cosmetics.
\end{abstract}

Keywords: brand loyalty, cosmetics products, purchase intention, Pakistan

\section{Introduction}

Across the Globe people are spending about US\$ 18 billion for cosmetics and players are playing their games in cosmetic field and many players are entering in this field for aggressive competition and to increase more and more market share. Cosmetics refer to as substantial and necessary items by attractiveness and appearance of human structure is increased. Cosmetic is "expected to be helpful for cleansing to the body of human being, advancing, giving a face-lift, prettiness," The cosmetic word refer as to the way a person show his/her clothing and stuff and this word is derived from Greek word koounokt text. Cosmetics are differ types and in different eras different things are used as a cosmetics'. In the modern society attractiveness and beauty are the vital and most desired elements. World has become the global village after 2000, before that in Pakistan the trend of using cosmetic was very little but now with the passage of time people are becoming more and more aware and becoming conscious about their personality due to which the usage of cosmetic and health care products are rapidly increasing and cosmetics industry is growing enormously due to which many competitors are entering the market and competition is increasing to gain a maximum market share. With the passage of 
time, competition has been increasing in the marketing setting and atmosphere of marketing is going to be more complicated than before...

Now, main purpose of businesses is to improve the efficiency and effectiveness of products which leads to create brand loyalty. It is recognized by firms that they can gain many benefits through building brand loyalty. If consumers are loyal with their brand then they will buy it again and again and will ready to pay even more price for that product which in turn will enhance the sales and profits of firms. Companies try to make more and more customers brand loyal to gain competitive advantage to become a market leader. Therefore, organizations needs to find methods for building and upholding brand loyalty such as through providing uniqueness toward brand and through achieving trust of customers. Loyalty plays an important role for the organization to gain competitive advantage over competitors as the loyal customer are less price sensitive and much quality time can be spent for competitive moves. An extremely enormous aphorism "Firms with the aim of effectively build up loyal consumers as well build up brand representative". When consumers choose a particular brand among many other competitive brands and repeatedly buy that branded product which demonstrates that consumers are really loyal with that brand. Firms considered brand loyalty as massive property for the reason that, firms can bring more and novel customers by providing less expensive goods that is compensated by the price which is extra charged from loyal consumers. Costumers pre-set some anticipation with a particular brand and buy the product to fulfill their desires. When consumers achieved those pre-set anticipations from a brand then consumer's trust is build up for a certain brand which refers to that consumers are satisfied. Customer satisfaction depends on the ways firms serve its consumers to fulfill their anticipations by providing goods and services efficiently and effectively. It has been recognized by firms that serving existing consumers is unproblematic and less expensive by satisfying their needs rather than efforts for attracting novel customers. It was stated that brand loyalty of customer is affected by the various feature which include brand name, promotion. Design, product quality, price and retail area environment of product in cosmetic industry (Lau et al., 2006). The main focus of these researches is on the factor that quality of brand effect the brand loyalty. Also studies that to what extend customers become loyal toward a product and what are the observations or opinion of consumers for a product which derive the attractiveness and observed quality by consumers of a brand. The principle of this paper is to examine the factors the effect brand loyalty of cosmetics industry of Pakistan and the effect of brand loyalty on the purchase intention of the customer.

\section{Literature review}

\subsection{Brand Name}

Brand name is anything which differentiates a product from others competitor's product in terms of sign, design, or any other factor. When a unique identification is given to a certain product as compared to competitors' product by using certain elements like design, name, symbol or mix of these is called brand name (American Marketing Association, 1960). A study done on the effect of brand loyalty on consumer sportswear in which it was concluded that positive and major link exist between band name and brand loyalty. A study examined that hard-core loyal customers and brand switchers are distinguished with the help of brand name. It was concluded that brand loyalty of hard-core loyal consumers is more affected by brand name (Lau et al., 2006). Consumer makes decision on the basis of brand image which is created through brand name that either it is same product that they want to purchase or not (Dolich, 1969). Brand names create the image of that particular brand in customers mind and help them to differentiate that brand with other. A good brand image is created through good brand name which assists in creating separate position of brand in the mind of consumer in comparison to competitors. Through which brand equity is build up for long time period (Aaker \& Keller, 1990). Popular brand name provides information about benefits drive from that popular 
branded product therefore consumers are more attracted toward popular brand name than a brand name that is not so popular (Kelle et al., 1998).

H1: There is a significant positive relationship between brand name and brand loyalty.

\subsection{Promotion}

Study done in sporting firms found that firms organize sport events and sponsor celebrities who have link with sport for promoting their brand (HKTDC, 2004). Promotion involves all methods of disseminating information about product to consumers which leads to increase in sales. Promotion is the source of providing information about a brand to the consumers. So advertisement creates a good image in the mind of consumers about a product or service as compared to competitor (Evans, Moutinho, \& Raaij, 1996). Seller's performance of providing service also affects the loyalty of consumer with brand (Evans, Moutinho, \& Raaij, 1996). Study concluded that, promotion is an effective way to compel the brand switchers toward a brand and building up brand loyalty because young people like to use a brand which sponsor famous people to promote the product (Lau et al., 2006). Promotion is the communication with the customers through advertisement; the customers are encouraged to purchase the product. Likewise service quality, that is to satisfy the needs and requirements of the customers with the help of sales person to make a healthy and long run relationship (Lau et al., 2006).

$\boldsymbol{H} 2$ : There is a significant positive relationship between promotion and brand loyalty.

\subsection{Design of product}

Design is a Visual emergence in which figure, line and facts are included which influence the consumer opinion towards brand. Loyal customers which are fashion conscious are attracted towards a brand which supply stylish package. The Followers of fashion and the leaders of fashion purchase normally those products and services in store which are highly fashionable and they also continue to purchase these products repeatedly. They feel satisfied as well as their ego is satisfied by using these most recent brands with latest designs (Frings, 2005). Cosmetics consumers becomes more conscious about fashion and they are demanding products and services with more recent style and design with attraction because they want to use special makeup designs and style for different functions or ceremonies (Duff, 2007). Fashion Conscious is usually known as understanding about Attractions and styling, awareness about Fashion changing trends, awareness about most recent designs and to purchase anything which is more exciting and trendier (Sproles \& Kendall, 1986). A complex list of Visual characteristics is generated and the most important factor which is identified is design or style. Customer's judgment is dependent on the extent to the level of which how much customer is fashion conscious, so the judgment will be specified to the opinion of the customers that which is presently fashionable. All the brands which produce stylish sportswear with great designs attract customers which are brand loyal and which are fashion conscious (Abraham \& Littrell, 1995).

H3: There is a significant and positive relationship between design of product and brand loyalty of consumers

\subsection{Product quality}

Some researches product quality is very much related to perception and they define product quality as a main attribute for the evaluation of product. Product quality is the main essential aspect in brand loyalty, as today world is a global village and more and more competitors are entering the market, so by providing a quality product will give a competitive advantage by improving own performance (Russell \& Taylor, 2006). The material, color and function of the brand should be according to the needs and expectations (Frings, 2005). Now day's customers are becoming more aware and they are unwilling to compromise on quality and consider this even more important than price of the product. The features of a particular brand are Product quality. Which has ability to satisfy the needs of customers? In other words, product quality is 
defined as "fitness for use" or "conformance to obligation". Customers do repeat purchasing if they are satisfied with the quality of the brand otherwise they will switch the brand (Russell \& Taylor, 2006).

H4: There is a significant and positive relationship between product quality and brand loyalty of consumers.

\subsection{PRICE}

Price Consciousness is also known as to find the worth buying on sale prices or low price choice (Sproles \& Kendall, 1986). Customers having more Brand Loyalty are ready to give extra price for their desired brand, so price cannot affect the purchase intention of those customers (Cadogan \& Foster, 2000). Customers have high confidence in the worth of brand and the price of brand as long as customers are ready to compare and monitor prices of their alternatives brand (Keller, 2003). Satisfaction of the customers can build by compare the price with superficial cost and value. So if the perceived value is more than the cost, it is experienced that customers will buy that brand or product. For medium consumer price is possibly the main significant factor. Customers having Brand Loyalty are ready to give a premium price even the price has enlarged because of the perceived risk is very high and these customers will pay a more price to overcome the risk of any change (Yoon \& Kim, 2000). Loyal customers discouraged by price evaluation with alternatives branded products by shopping around and service loyalty of long term relationship build brand loyal customers which are more prices tolerant. Now price become a central point regarding assessment of offer value as well as to access the retailer (De Ruyter, Wetzels, \& Van Birgelen, 1999). Price is the main factor which shows in the market the company's value positioning of its brand and product (Abraham \& Littrell, 1995).

H5: There is a significant and positive relationship between price and brand loyalty of consumers.

\subsection{Store Environment}

An extensive amount of research has been done on the impact of store environment on consumer behavior. The main and positive attribute of the store are, store place, layout, interior in-store stimuli of the store that effect the brand loyalty. If the store location is out of reach and store outlets are less then it will impact on purchasing pattern and consumer shopping and customer will not go to another shop for that brand rather they will switch the brand and choose another brand, like wise if the store is highly accessible and customers are satisfied with the service then these consumers will be loyal after wards (Evans, Moutinho, \& Raaij, 1996). Store environment plays an important role in influencing the decision making. In today's competitive world store environment has been considered as the most important attribute as it is the point of purchase for the consumers. Due to increase in competition the retailer has realized the importance of store environment as it delights the purchase experience of consumers that enhances brand loyalty (Muge \& Tunkay, 2003). The stimuli in the store are sales person, temperature, smell, display, sign, sound and color are the attributes of store environment, that in return influence customer satisfaction and decision making process (Abraham \& Littrell, 1995). If the store has low beat music it will lead to more sale volume as customers will spend more time in the store (Evans, Moutinho, \& Raaij, 1996).

H6: There is a significant and positive relationship between store environment and brand loyalty of consumers.

\subsection{Purchase Intention}

"The plan in which a person intends to buy a special goods or service sometime in the near future". 
If consumers are loyal with a brand then price will not impact on their buying behavior like they will ready to pay more for their favorite brand. Furthermore consumers have confidence that the brand they like provide more benefits to them than the cost charged (Evans, Moutinho, \& Raaij, 1996). Consumer's choice of buying product depends on what styles people are adopting and which fashion is in (Abraham \& Littrell, 1995). The purpose of this study is to evaluate the influence of past experience and consumer value on purchasing intention of personal care products. The study shows that the retailers enhance the intention of consumer for purchasing organic care product by using the efficient marketing strategies like emphasizing on natural beauty, product security and reasonable prices. It is difficult for the implication of marketing strategies without the understanding of consumer behavior (Rokeach, 1973). This study shows that the consumer show different behavior toward organic personal care product in different value system. The values affected on consumer attitude toward buying organic product and he/she will look for those products which satisfy their values (Grunert \& Juhl, 1995). The study purposes the three consumer values first is "health awareness" people involve in healthy behavior and try to maintain healthy behavior (Becker et al., 1977) second is "environmental consciousness "in which people engage in changing their purchasing behavior to develop the environment (Chase, 1991) and finally the third one is "appearance consciousness" lead the people to engage in cosmetics or clothing that communicate or alter their image (Lee \& Lee, 1997). It was concluded that purchase intention depend on the consumer's ability to pay for a particular product. When consumers have enough money they don't consider either product is expensive or cheaper. When consumers have more purchase intention then consumers will be more loyal towards a brand and will consider a particular brand more while making purchase decision. Mostly students are dependent such as they have expenses but don't have earnings. In order to take the advantages which are associated with original brand they are attracted towards the counterfeits due to low price. Students are believed to be identical relative to their behavior (Calder, Philips, \& Tybout, 1981). Students are selected for conducting this study Peer pressure refers as People make a certain class or group, every person want to belong with that group consciously or unconsciously. For this purpose they change themselves according to the characteristics of that class or group (Clasen $\&$ Brown, 1985). Purchasing behavior of consumer is extensively affected by pressure of peer from a specific group therefore group keeps significance in considerate of purchase intention. Value Consciousness refers as buy a less expensive product by sacrificing a little quality so this behavior of consumer effect the purchase of counterfeits (Bloch, Bush, \& Campbell, 1993; Ang et al., 2001; Wang et al., 2005).

H7: There is a significant positive relationship between purchase intention and brand loyalty.

\section{Hypotheses and research model}

On the basis of the literature review, the current study tests the following hypotheses.

H1: There is a significant positive relationship between brand name and brand loyalty.

H2: There is a significant positive relationship between promotion and brand loyalty.

H3: There is a significant positive relationship between design and brand loyalty.

H4: There is a significant and positive relationship between product quality and brand loyalty of consumers.

H5: There is a significant and positive relationship between price and brand loyalty of consumers.

H6: There is a significant and positive relationship between store environment and brand loyalty of consumers

H7: There is a significant positive relationship between purchase intention and brand loyalty. 


\section{Theatrical frame work}

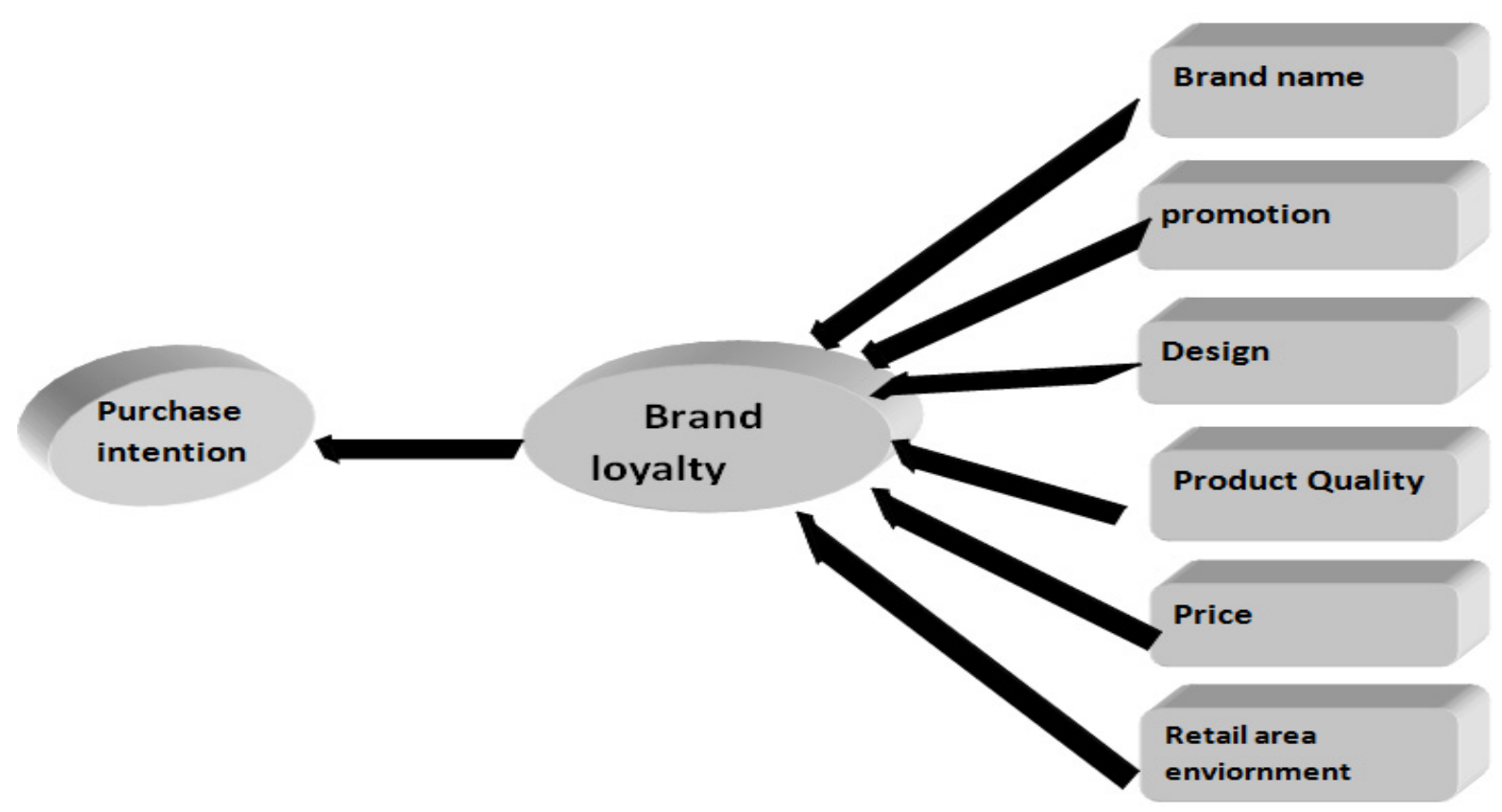

Figure 1. Hypothetical model

\section{Research \& methodology}

\subsection{Methodology}

Current researches nature is a descriptive type; this type of research explained or described some phenomenon at any specific situation. A descriptive quantitative method was used to determine the different aspects. Structure question was used for the quantitative research methods; it is used as a preferable method to find out the different aspect of respondent behavior (Ghauri \& Cateora, 2010).

\subsection{Sample selection}

In this study, females were focused to collect the data, about the impact of brand loyalty on purchase attention in cosmetics products. Females were selected as a sample because females are more interested in buying the cosmetic products. Cosmetics was selected because it is a product to which females pay great concentration while making the buying decision because of it's perceive value in increasing their appearance.

\subsection{Research instrument}

Structured Questionnaire technique was used to collect the data. The questionnaire start with an preparatory statement that requests respondents to do help in doing this research by directing their own responses, guaranteed them of discretion, and so forth. This was followed by an appeal for demographic information and the events. Oral guidance was also given to respondents about filling the questionnaire. A total of 90 questionnaires were distributed out of which 10 were incomplete responses and 80 questionnaires were received with complete responses.

\subsection{Procedure}

Structured questioner was distrusted to the 100 females (students) at DMS Islamia university of Bahawalpur .sample was selected on the basis of random convenient sampling and students was choosing because students are the collection of different cultures and status, and beauty 
conscious peoples .Female students was the correct sample to obtain response 100 questioner was distributed from 80 questioner was used to spss sheet.

\subsection{Instruments and measure}

For this research paper already published scale was used to measuring the response first four scale brand loyalty ,brand name, product quality and price ware taken (Khraim, 2011), and purchase decision, store environment, design and promotion ware taken from (Gillani, Yousaf, \& Khan, 2013).

Table 1. scale of the study

\begin{tabular}{|c|c|c|c|}
\hline No & Variable & Item & Reference \\
\hline 1 & Brand loyalty & $\begin{array}{l}\text { - The brand you purchase satisfies you } \\
\text { - Would you like to purchase product of this } \\
\text { company again } \\
\text { - Would you like to recommend products of this } \\
\text { company to your friends and family }\end{array}$ & $\begin{array}{lr}\text { Dr. } & \text { Hamza } \\
\text { Khraim (2011) }\end{array}$ \\
\hline 2 & Brand Name & $\begin{array}{l}\text { - } \quad \text { The brand is reputable } \\
\text { - } \quad \text { Brand Name and Image magnetize me to } \\
\text { purchase } \\
\text { - } \quad \text { Brand Name is selected apart from price } \\
\text { - } \quad \text { Brand reflects my own personality } \\
\text { Products of this brand you purchase satisfy you }\end{array}$ & $\begin{array}{cc}\text { Dr. } & \text { Hamza } \\
\text { Khraim (2011) }\end{array}$ \\
\hline 3 & Product Quality & $\begin{array}{l}\text { - The brand stay longer than other brands } \\
\text { - The materials used by the brand are natural } \\
\text { - The brand has adequate color } \\
\text { - The brand has superior functional quality }\end{array}$ & $\begin{array}{l}\text { Dr. Hamza } \\
\text { Khraim }(2011)\end{array}$ \\
\hline 4 & Price & $\begin{array}{l}\text { - } \quad \text { Increases of price not hamper me to purchase } \\
\text { - } \quad \text { The brand provides goods rate for money } \\
\text { - } \quad \text { The brand we use, charge fear prices. } \\
\text { - } \quad \text { Comparatively the brand we use charge low price }\end{array}$ & $\begin{array}{lrr}\text { Dr. Hamza } & \text { Salim } \\
\text { Khraim (2011) } & \end{array}$ \\
\hline 5 & $\begin{array}{l}\text { Purchase } \\
\text { Decision }\end{array}$ & $\begin{array}{l}\text { - While purchasing cosmetics you consider friends } \\
\text { and family suggestions } \\
\text { - } \quad \text { Purchase of cosmetic is a complex decision } \\
\text { - I take my own decision for the purchase cosmetic } \\
\text { - Would you like to purchase goods from this } \\
\text { company again } \\
\text { - It took me less time to purchase cosmetic item. }\end{array}$ & $\begin{array}{l}\text { SYEDA } \\
\text { GILLANI et al.,(2013) }\end{array}$ \\
\hline 6 & $\begin{array}{l}\text { Store } \\
\text { Environment }\end{array}$ & $\begin{array}{l}\text { - The brand has good store locality } \\
\text { - The brand has an adequate outlets } \\
\text { - The interior display is good } \\
\text { - Color and music inside the store are attractive } \\
\text { - } \quad \text { Does this brand have an extensive stock that can } \\
\text { cater to the needs of a customers }\end{array}$ & $\begin{array}{l}\text { SYEDA } \\
\text { GILLANI et al.,(2013) }\end{array}$ \\
\hline 7 & Design & $\begin{array}{l}\text { - } \quad \text { The brand provides broad range of designs } \\
\text { - } \quad \text { Designs of the brand are appropriate for me } \\
\text { - } \quad \text { Designs of the brand have unique features } \\
\text { - } \quad \text { Designs of the brand are stylish and fashionable }\end{array}$ & $\begin{array}{l}\text { SYEDA FAIZA } \\
\text { GILLANI et al.,(2013) }\end{array}$ \\
\hline 8 & Promotion & $\begin{array}{l}\text { - } \quad \text { Ads of the brand is striking } \\
\text { - } \quad \text { Ads of the brand attract me to buy } \\
\text { - } \quad \text { indow outlooks are attractive }\end{array}$ & $\begin{array}{l}\text { SYEDA } \quad \text { FAIZA } \\
\text { GILLANI et al.,(2013) }\end{array}$ \\
\hline
\end{tabular}




\section{Macrothink}

\section{Reliability analysis}

Cronbach alpha of all items of the questioner was 0.811.the results shows that all items ware reliable and valid to measure the attitude of consumers (purchase intention) of cosmetics products. Table 2 shows the value of Cronbach's Alpha of every variable. Almost every variable shows the higher value of Cronbach's Alpha except Design, Store Environment and Purchase Intention which have average reliability. The value of Cronbach's Alpha of variables areas, $($ Brand name $=0.504),($ Price $=0.769),($ Design $=0.474),($ Promotion $=0.607),($ Store Environment $=0.477)$, (Product Quality $=0.708)$, and $($ Purchase Intention $=0.426)$. There are seven independent variables of brand loyalty which are tested by the researcher and questionnaire is distributed to the respondent and the liker scale is used, 1 show strongly disagrees, 2 shows disagree, 3 shows neutral, 4 shows agree and 5 shows strongly agree. The Table shows the results of the analysis. Result shows that seven variables are significant as Brand Name (0.000), Price (0.009), Design (0.000), Promotion (0.002), Store Environment (0.005), Product Quality (0.000), and Purchase Intention (0.003).

Table 2. Reliability of measurement instrument

\begin{tabular}{|l|l|}
\hline scales & Cronbach's Alpha \\
\hline Brand name & 0.504 \\
\hline Price & 0.769 \\
\hline Design & 0.474 \\
\hline Promotion & 0.607 \\
\hline Store environment & 0.477 \\
\hline Product quality & 0.708 \\
\hline Purchase intention & 0.426 \\
\hline
\end{tabular}

\section{Hypothesis Testing}

Regression analysis was used to measure the impact of 6 variables on brand loyalty and impact of brand loyalty on purchase intention in cosmetics products. In this study two demographic variables are included which are age, and educational level. Six variables brand name, promotion, design, product quality, price, and retail area environment are taken as independent variables to measure the impact on dependent variable brand loyalty. Brand loyalty is considered as dependent variable to measure the impact on independent variable purchase intention.

Table 3. Regression and results

\begin{tabular}{|l|l|l|l|l|l|l|}
\hline variable & R Square & Adjusted R & F-test & t-test & beta & Significant \\
\hline Brand name & 0.331 & 0.322 & 38.510 & 6.206 & 0.788 & 0.000 \\
\hline Price & 0.085 & 0.073 & 7.217 & 2.687 & 0.428 & 0.009 \\
\hline Design & 0.191 & 0.181 & 18.414 & 4.291 & 0.478 & 0.000 \\
\hline Promotio & 0.115 & 0.103 & 9.960 & 3.156 & 0.370 & 0.002 \\
\hline Store environment & 0.098 & 0.086 & 8.436 & 2.904 & 0.347 & 0.005 \\
\hline Product quality & 0.393 & 0.386 & 50.599 & 7.113 & 0.693 & 0.000 \\
\hline Purchase intention & 0.104 & 0.093 & 9.083 & 0.003 & 0.252 & 0.003 \\
\hline
\end{tabular}




\subsection{Brand Name and Brand Loyalty}

2018, Vol. 5, No. 1

The regression results shows in table 3 that there is significant positive association between brand name and brand loyalty with $(\mathrm{B}=0.788)$ and $(\mathrm{p}<0.05)$. According to all these results, Brand names contribute more than 78 percent to the Brand Loyalty. If we increase the brand name by the percentage of 78 percent then it will increase the level of brand loyalty by the same percentage. These results support and confirm the Hypothesis 1.

\subsection{Price and Brand Loyalty}

The result shown in table 3 that there is significant positive association between price and brand loyalty with $(B=0.428)$ and $(p<0.05)$. These results shows that price contribute more than 42 percent towards brand loyalty. Thus result confirms and validates the Hypothesis 2.

\subsection{Design and Brand Loyalty}

The results indicates in table 3 that there is a significant positive association between Design and Brand Loyalty with $(\mathrm{B}=0.478)$ and $(\mathrm{p}<0.05)$. This result suggests that design will contribute more than 47 percent towards brand loyalty. The result of the study supports and validates Hypothesis 3.

\subsection{Promotion and Brand Loyalty}

Results and analysis of this study is showing in table 3 that there is a considerable positive association between promotion and brand loyalty with $(B=0.37)$ and $(\mathrm{p}<0.05)$, which means that promotion contribute more than 37 percent to the brand loyalty. Based on these results we accept hypothesis 4 and conclude that there is positive significant relationship between promotion and brand loyalty.

\subsection{Store Environment and Brand Loyalty}

This study shows in table 3 that there is a positive considerable association between Store Environment and Brand Loyalty with $(\mathrm{B}=0.347)$ and $(\mathrm{P}<0.05)$, which shows that store environment is contributing more than 34 percent to the brand loyalty. Based on these results we accept the hypothesis 5 and conclude that there is positive considerable association between store environment and brand loyalty.

\subsection{Product Quality and Brand Loyalty}

The Results of this study shows in table 3 that there is positive association between Product Quality and Brand Loyalty with $(\mathrm{B}=0.693)$ and $(\mathrm{p}<0.05)$, showing that product quality is contributing more than 69 percent to the brand loyalty. All these results support and validate hypothesis 6.

\subsection{Purchase Intention and Brand Loyalty}

This Study showing in table 3 that there is considerable positive association between purchase intention and brand loyalty with $(\mathrm{B}=0.252)$ and $(\mathrm{p}<0.05)$. These results indicates that purchase intention contribute more than 25 percent towards brand loyalty. On the basis of these results we can say that hypothesis 7 is accepted

\section{Conclusion}

This paper aims to explore the impact of variables brand name, promotion, design, product quality, price, retail area environment on the brand loyalty and also the impact of brand loyalty on purchase intention. It is concluded that brand name, promotion, design, product quality, price, retail area environment has considerable positive impact on brand loyalty and brand loyalty has also significant positive impact on purchase intention. Results indicate that consumer become loyal when a good brand name is created so first hypothesis H1 is accepted. In current competitive environment, it becomes necessary for the firms to build brand loyalty so firms should focus on generating the good brand name. $\mathrm{H} 2$ is accepted as significant positive relationship is found between promotion and brand loyalty. Promotion is an effective way to 
compel the brand switchers toward a brand and building up brand loyalty because young people like to use brands which sponsor famous people to promote the product. H3 is accepted. Cosmetics consumers becomes more conscious about fashion and they are demanding products and services with more recent style and design with attraction because they want to use special makeup designs and style for different functions or ceremonies. H5 is accepted as significant relationship is found between price and brand loyalty. Customers having Brand Loyalty are ready to give a premium price even the price has enlarged because of the perceived risk is very high and these customers will pay a more price to overcome the risk of any change and become loyal. A significant positive relationship exists among product design and brand loyalty therefore Product quality and Store environment has considerable positive association with brand loyalty therefore $\mathrm{H} 4$, and $\mathrm{H} 6$ are also accepted. Brand loyalty has significant positive relationship with purchase intention therefore $\mathrm{H} 7$ is accepted. So the actors of the cosmetics industry might create the brand loyal customers on focusing H1 to H6.

\section{References}

Aaker, D. A., \& Keller, K. L. (1990). Consumer evaluation of brand extension. Journal of Marketing, 54, 27-41.

Abraham, M. L., \& Littrell, M. A. (1995). Consumer's conceptualization of apparel attributes. Clothing and textile research journal, 13(2), 65-74.

American Marketing Association. (1960), Marketing Definitions: A Glossary of Marketing Terms, AMA. Chicago, IL.

Ang, S. H., Cheng, P. S., Lim, E. A. C., \& Tambyah, S. K. (2001). Spot the differences: consumer responses towards counterfeits. Journal of Consumer Marketing, 18(3), 219-35.

Becker, M., Maiman, L., Kirscht, J., Haefner, D., \& Drachman, R. (1977). The health belief model and prediction of dietary compliance: a field experiment. Journal of Health and Social Behavior, 18(4), 348-66.

Bloch, P. H., Bush, R. F., \& Campbell, L. (1993). Consumer accomplices in product counterfeiting: A demand-side investigation. Journal of Consumer Marketing, 10(4), 27-36.

Cadogan, J. W., \& Foster, B. D. (2000). Relationship Selling and Customer Loyalty: An

Calder, B. J., Philips, L. W., \& Tybout, A. M. (1981). Designing research for application. The Journal of Consumer Research, 8(2), 197-207.

Chase, D. (1991). The green revolution: P\&G gets top marks in AA survey. Advertising Age, 62(5), 8-10.

Clasen, D. R., \& Brown, B. B. (1985). The multidimensionality of peer pressure in adolescence. Journal of Youth and Adolescence, 14, 451-468.

De Ruyter, K., Wetzels, M., \& Van Birgelen, M. (1999). How Do Customers React to Critical Service Encounters: A Cross-sectional Perspective. Total Quality Management, 10(8), 1131-1145.

Dolich, I. J. (1969). Congruence relationship between self image and product brands. Journal of Marketing Research, 6(1), 80-4.

Duff, M. (2007). Niche Marketing of cosmetics. DSN Retailing Today, 38, 29-35.

Empirical Investigation. Marketing Intelligence and Planning, 18, 185-199.

Evans, M., Moutinho, L., \& Raaij, W. F. V. (1996). Applied consumer behavior. Addison-wesley Pub. Co., Harlow; reading, Mass. 
Frings, G. S. (2005). Fashion: From Concept to Consumer (8th Ed.). Pearson/Prentice Hall: New Jersey.

Ghauri, P. N., \& Cateora, P. (2010). International Marketing (3rd Ed.). Berkshire: McGraw-Hill Education.

Gillani, S. F., Yousaf, S., \& Khan, S. (2013). The Effect of Brand Characteristics on Brand Loyalty A Study of Cosmetics Products in Peshawar Pakistan. International Review of Basic and Applied Sciences, 1(1), 1-11.

Grunert, S., \& Juhl, H. J. (1995). Values, environmental attitudes, and buying of organic foods. Journal of Economic Psychology, 17(1), 39-62.

HKTDC (Hong Kong trade development council). (2004). Profiles of hong kong major manufacturing industries: hong kong'ssporting goods industry. Retrieved from http://www.com/main/industries/t2234.htm

Kelle, K. L., Heckler, S. E., \& Houston, M. J. (1998). The effect of brand name suggestiveness on advertising recall. Journal of marketing, 62(1), 48-57.

Keller, K. L. (2003). Strategic brand management: building, measuring and management brand equity. Prentice hall, upper saddle river, NEW Jersey.

Khraim, D. H. (2011). The Influence of Brand Loyalty on Cosmetics Buying Behavior of UAE Female Consumers. International Journal of Marketing Studies, 3(2), 123-133.

Lau, M.-M., Chang, M.-T., Moon, K.-L., \& Liu, W.-S. (2006). the brand loyalty of sportswear in hong kong. Journal of textile and apparel,technology and management, 5(1), 1-13.

Lee, M., \& Lee, E. (1997). A study on appearance interest and self-confidence of elderly women associated with demographic variables. The Korean Society of Clothing and Textiles, 21, 1072-81.

Muge, Y., \&Tunkay, K. (2003). The effect of store atmosphere attributes on store loyalty intentions of hypermarket/supermarket customers.

Rokeach, M. (1973). The Nature of Human Values. Free Press, New York, NY.

Russell, R. S., \& Taylor, B. W. (2006). Operation Management: Quality and Competitiveness in a Global Environment ( $5^{\text {th }}$ Ed.). John Wiley \& Sons, Inc.: River Street.

Sproles, G. B., \& Kendall, E. L. (1986). A methodology for profiling consumer decision -making design. The Journal of Consumer Affairs, 20, 267-279.

Wang, F., Zhang, H., Zang, H., \& Ouyang, M. (2005). Purchasing pirated software: an initial examination of Chinese consumers. Journal of Consumer Marketing, 22(6), 340-51.

Yoon, S. J., \& Kim, J. H. (2000). An Empirical Validation of a Loyalty Model based on Expectation and Disconfirmation. Journal of Consumer Marketing, 17(2), 120-136.

\section{Copyright Disclaimer}

Copyright reserved by the author(s).

This article is an open-access article distributed under the terms and conditions of the Creative Commons Attribution license (http://creativecommons.org/licenses/by/3.0/). 